\title{
Appelation(s): Naming, Labelling, Addressing. Introduction
}

\section{Charlotte Sturgess}

\section{(2) OpenEdition \\ 1 Journals}

Electronic version

URL: https://journals.openedition.org/ces/5258

DOI: $10.4000 /$ ces.5258

ISSN: 2534-6695

\section{Publisher}

SEPC (Société d'études des pays du Commonwealth)

\section{Printed version}

Date of publication: 1 September 2013

Number of pages: 5-7

ISSN: 2270-0633

\section{Electronic reference}

Charlotte Sturgess, "Appelation(s): Naming, Labelling, Addressing. Introduction", Commonwealth Essays and Studies [Online], 36.1 | 2013, Online since 16 April 2021, connection on 22 July 2021. URL: http:// journals.openedition.org/ces/5258; DOI: https://doi.org/10.4000/ces.5258

\section{(2) $(\mathbb{Q} \Theta \Theta$}

Commonwealth Essays and Studies is licensed under a Licence Creative Commons Attribution - Pas d'Utilisation Commerciale - Pas de Modification 4.0 International. 


\section{Introduction}

The name hidden in its potency possesses a power of manifestation and occultation, of revelation and encrypting. What does it hide? Precisely the abyss that is enclosed within it. To open a name is to find in it not something but rather something like an abyss, the abyss as the thing in itself.

Derrida, 226-7

The collection of articles in this issue of Commonwealth Essays and Studies constitutes an investigation into the epistemological premises and the discursive instances of a culturally fraught and interlinked set of terms: naming, labelling, addressing. The articles emerge from, and reflect a whole spectrum of perspectives on the literatures of Australia, the Caribbean, Asia and Canada: this diversity of textual material sheds light on the very complexity and instability of the terms themselves. For when one considers the effect of naming in a colonial context the spectre of territorial expropriation, slavery, exploitation and the erasure of Indigenous identities raises its ugly head. When one considers labels in the context of war, trauma, displacement and persecution come to mind.

Pitted against the violence of historical legacies and ongoing struggles for recognition are the literary responses examined in this volume. As a whole they reveal that naming is both ontological and discursive. It founds collective and individual identities, conferring a sense of community or selfhood, but it also, in the very act of conferring, reveals the constructedness of identities themselves. For names are not coterminous with ontology, rather they "perform" ontological identity, in often fundamental ways and to noble ends, allowing bonds within, between and across communities, allowing for the imagining of common ties at great geographical distances, as is the case for diasporic populations. Naming, precisely because it is performative and not an essence also allows for un-naming and renaming, thus opening up a vista for the reconfiguring of colonial violence as reclaimed cultural and social space.

In the words of Stuart Hall cultural identity is:

[a] matter of "becoming" as well as of "being." It belongs to the future as much as to the past. It is not something which already exists, transcending place, time, history and culture. Cultural identities come from somewhere, have histories. But like everything which is historical, they undergo constant transformation. Far from being eternally fixed in some essentialised past, they are subject to the continuous "play" of history, culture and power. (394)

Precisely because names both confer identity and, by doing so, underline the slippery nature of such conferral, the works in this volume raise the question of how fiction and poetry deal with, and deal in history; that is, how the realm of the imagination provides a myriad of vantage points and perspectives from which to examine the tensions and complexity of colonial legacies, racial discrimination and diasporic scattering. Interes- 
tingly, the articles raise more questions than provide answers and open a fruitful, and necessarily ongoing debate on, for example, the nature of power relations in a given cultural context. Does, for instance, recognising the ills of colonial violence automatically wipe the slate clean and enable equality between perpetrator and victim? Is "reclaiming" an identity a gateway to freedom or merely a passage to another essentialist category? Can writing the self through the prism of historical events and characters open up the past to a form of constructive humanism?

The first essay in this volume takes up the issue of what is at stake in the revisiting of Australia's frontier history in Kate Grenville's The Secret River. Sheila CollingwoodWhittick explores the permeable boundary within historiographical fiction between the effort to shed light on the atrocities inflicted on the Aboriginal population during colonial settlement, and an exculpatory rhetoric founded in a sentimental treatment of exconvict settlers. Thus, through her reliance on strategies of naming, Grenville, despite her avowed wish to depict a truthful picture of events, constructs a settler romance with the land that overwrites the script of dispossession it intends to foreground. In contrast with this probing of the hard core of dissent still fuelling debate on Australian settler attitudes towards the past, Salhia Ben-Messahel shows how fiction that overtly plays with familiar historical identities, by creating a slippery surface of multiple perspectives, shifts the focus from a re-examination of history to that of names as a set of mobile identifications.

But naming is not only a question of labelling, it also constitutes the subject's relation to desire and to roots, as Myriam Moïse's article on Caribbean short stories demonstrates. Taking as her focus two fictions from the kitchen story genre, she shows how Philip and Hopkinson exploit and subvert the formulaic aspect of the recipe, thus reinvesting the traditionally over-determined and constraining women's domestic domain with a linguistic mixing of forms. Orality and the body are here the interwoven sites of a feminine aesthetics that is equally a discursive space of agency: a "limbo subjectivity" as the author states.

In his article David Bousquet approaches the problem of naming in a Caribbean context from an alternative perspective, that of dub poetry, a performance genre linked to reggae music where the poet-musicians' staging of Africanised names is part of a strategy of re-appropriation through invention. If, as Bousquet says, such poetry in performance means naming names as an invocation - a rendering present - we are reminded of Judith Butler's take on Althusser's concept of interpellation whereby namecalling, although a form of social injury, also entails a recognition of subjective agency and thus invites the subject, thus interpellated, to political action (Introduction n.p.).

Kathie Birat's examination of Caryl Phillip's work completes this section on Caribbean texts, and affords a different focus on the link between naming, history and writing. Exploring the liminal space between autobiography and biography, between the truth contract of the latter and the more overtly fictional narrating position of the former, this essay shows how Phillip uses names of real historical figures through an ethical focus: that of witnessing and responsibility. Names here engage the narrating subject in a creative relation with the past.

Such an ethical stance is also to be found in Astrid Lohöfer's exploration of the relationship between Canadian modernist poetry and moral values. Contending that poetry can engage with life in a cogent fashion, as a form of creative world-disclosure, 
the author seeks to transcend the conventional binary opposing aesthetics and ethics in relation to poetry and thus invalidate the labels currently used to define the lyric.

Next in the volume comes another piece on Canadian literature and labelling: Corinne Bigot's article on the Japanese-Canadian author Joy Kogawa's Obasan. Obasan was the first novel to reveal the atrocities perpetrated against Canadians of Japanese decent during World War II. Bigot shows how the narrative's tensions gravitate around the problem of naming: the desire to undo racist categorisations yet to reclaim a Canadian identity. She demonstrates how the novel puts in play linguistic code switching, generic slippage, and the semantic overlap of geography and territory in order to create a hybrid textual identity. Names can thus never fully account for that which they seek to designate or staple down; they are always exceeded by the plethora of meanings they attempt to limit.

Lastly, also concerned with naming as labelling, is Françoise's Král's article on The Namesake by Jhumpa Lahiri. Deflecting the focus away from the psychological interpretation the novel is usually subjected to, the author posits that the notions of mis-naming and mis-labelling allow for a more crucial reading of the politics of this diasporic text. Thus, the question of subjective positioning in relation to categorisation is raised, as well as the up to now unexamined tragedy of migrant populations who are afforded no label and therefore no social identity.

As these few words in guise of an introduction indicate, this collection of articles offers a very wide spectrum of perspectives on the question of naming, labelling and mis-naming. It demonstrates that post-colonial and diasporic literatures provide a rich epistemological field within which to ponder that ever haunting question: "What is in a name?"

Charlotte STURGESS

University of Strasbourg

\section{Works Cited}

ButLer, Judith. Introduction. Excitable Speech: A Politics of the Performative. New York: Routledge, 1997.

DerRiDA, Jacques. "The Eyes of Language: The Abyss and the Volcano." Acts of Religion. Ed. Gil Anidjar. New York: Routledge, 2002. 189-227.

HALL, Stuart. "Cultural Identity and Diaspora." Colonial Discourse and Post-colonial Theory: A Reader. Ed. Patrick Williams, and Laura Chrisman. London: Harvester Wheatsheaf, 1994. 392-401. 